\title{
Criminal Law Scholarship : Should It Be Able to Present Itself as Science?
}

\section{Nuotio, Kimmo}

Nomos

2021-06

Nuotio , K 2021, Criminal Law Scholarship : Should It Be Able to Present Itself as Science? in S Matsuzawa \& K Nuotio (eds), Methodology of Criminal Law Theory : Art, Politics or Science? . Studien zur Strafrechtstheorie und Strafrechtsethik, vol. 4 , Nomos, Baden-Baden , pp. 77-103 . https://doi.org/10.5771/9783748904755-77

http://hdl.handle.net/10138/338985

https://doi.org/10.5771/9783748904755-77

unspecified

acceptedVersion

Downloaded from Helda, University of Helsinki institutional repository.

This is an electronic reprint of the original article.

This reprint may differ from the original in pagination and typographic detail.

Please cite the original version. 
This is a draft chapter. The final version is available in S Matsuzawa \& K Nuotio (eds), Methodology of Criminal Law Theory: Art, Politics or Science?. Studien zur Strafrechtstheorie und Strafrechtsethik, vol. 4, Nomos, Baden-Baden, pp. 77-103. www.nomos-elibray.de https://doi.org/10.5771/9783748904755-77 


\title{
Criminal Law Scholarship - Should It Be Able to Present Itself as Science? Kimmo Nuotio
}

\author{
Kimmo Nuotio
}

\section{The Finnish entrance point}

It makes indeed sense to try to figure out if criminal law scholarship could or should be regarded as science. It would help defend criminal law in the eyes of other sciences if we could show that it rests on the solid footing of science. Unfortunately this exercise will not be easy. The topic is not new since at least after the rise of the natural sciences, social sciences and humanities have generally been set under the pressure to define themselves as sciences. Law is no exception to that.

In fact, if we look at text-books for criminal law, we rather rarely find any deeper considerations as regards to the scientific character of criminal law scholarship. In most cases, the text-books run simply from the basic concepts and principles, discuss the legal sources and how to interpret them, etc. It seems that the criminal law scholarship has outsourced some of its foundational questions to philosophy of law and legal theory. Criminal law theory may have been mainstreamed in the sense that a doctrinal approach to penal liability simply moves in internal circles, as a fight between different theoretical positions, and without any need to refer to deeper sources of the doctrines. Doctrines may thus work as stop rules for legal reasoning.

First, we need to differentiate between criminal law and criminal law scholarship. It makes sense to see a difference here. We would talk about practices of criminal law, and even about norms of criminal law, even if we had no particular science looking at it. The practices we have had for centuries, much before we started theorizing about them.

Science produces knowledge, and criminal law as an object of science emerges as a separate body of knowledge. In the German scholarly tradition, the $19^{\text {th }}$ century saw first a wave of 
Hegelian idealism, followed by a von Lisztian sociological realism. The birth of the Finnish criminal law science connects directly with a Hegel-inspired scholarship ${ }^{1}$ which, for that matter, consolidated itself in the Finnish Penal Code of 1889/1894. From those years onwards we can see that the Finnish criminal law scholarship has grown and matured under this tension between classical (and later neo-classical) ideas and a conscious sociological, social policy oriented view about crime and criminal law. ${ }^{2}$

During the heyday of Scandinavian legal realism in the 1940's and 1950's the Finnish criminal law theory was not very strong and receptive. We could rather see that there were different strands of conservative thought, some of it more liberal, some more conservative. But in those debates theories of knowledge were not present. It was probably only in the 1960's that the criminal lawyers' monopoly to discuss crime was challenged and the practices of crime control were challenged by many experts representing a variety of other academic areas. The famous Nordic critical criminology started getting criminal law professors involved, and it all led to critical reformist criminal policy ideas.

Thus, in Finland we actually never entered a serious debate about whether what we do is scientific. The critique of criminal law by the reformers was a justice critique, and the old school had to give room to new thought since the belief in special prevention and treatment of the offenders had simply lost credibility. ${ }^{3}$ The academic critique was not the only reason for reform, since the entire society was receptive to reformist ideas, and the reforms carried out were many. A project was started to reform the entire body of criminal law. First, a committee worked on the leading principles that would have to be followed, and later the project was carried through.

\footnotetext{
${ }^{1}$ Markus Wahlberg, Den finska straffrättsvetenskapens födelse I. Forum iuris 2003.

${ }^{2}$ Cf. Kimmo Nuotio, "The Reform Story of the Finnish Penal Code: Ideological turns and waves of modernization," in Goodall, K., Malloch, M. and Munro, B. (eds.), Building Justice in Post-Transition Europe? Processes of Criminalisation within Central and Eastern European countries, Abingdon and Oxon: Routledge, 2013, pp. 78-93; Kimmo Nuotio, "The transformation of criminal law and criminal law theory in Finland and China, Peking University Law Journal, 5:1, pp. 1-23, DOI: 10.1080/20517483.2017.1330807.

${ }^{3}$ See, generally, on the debate within Nordic criminal law as well as concerning the Finnish situation, Juhana Mikael Salojärvi, A Menace to Society. Radicalism and Legal Scholarship in the United States, Scandinavia and Finland, 1965-1980. Faculty of Law, University of Helsinki, 2013, p. 195-214, 300314.
} 
In the 1970's neo-classical thought took the lead since this was sort of a common denominator that many could agree on. Act-proportionality and similar values of justice were being stressed. This justice thinking was, however, rather socially informed, and the idea was to redefine the role criminal law should play in a modernizing society. For that purpose one needed criminal policy insights. The aim was to tailor criminal law to serve rational and humane criminal policy interests and to avoid excesses of use of criminal law. Traditional criminal law was suspected even to have been a tool for suppressing people with a lower social status. Theory and practice of criminal policy were a primary interest, and 1970's or 1980's were decades of updating and real reform, and there was less effort yet to theorize how a modern doctrine of criminal liability should look like. We should also note that in the philosophical debates analytical philosophy of action became one source of inspiration, as can be seen in the dissertation on criminal intent of Nils Jareborg from 1969, to give just bone example. ${ }^{4}$ The former rigid positivism gave way to the idea that language should be the main target of our interest since we only can reach truths by means of language. In Finland the interest in analytical philosophy could also be observed, but it became important mainly in other areas of legal scholarship, rather than in criminal law.

Only after the reforms of the special part of criminal law had already started, began the thinking of how structures of penal liability should be construed in a modernized society. In the 1990's the need for a rethinking was already pressing, since in 1995 areas such as safety at work crimes and environmental crimes had been revised, and it was obvious that new doctrines were needed concerning how to allocate penal liability in organisations. Even a corporate penal liability had been introduced.

To cut the long story short, we could say that once again the Finnish criminal law scholars had to try to make the best out of what was available. There was the own Finnish legal and scholarly tradition, but you also wanted to understand the legal models that were being discussed in other Nordic countries, especially in Sweden, as well as the in the German scholarship. The Finnish perspective was pragmatist, and the idea was to adopt what works but to avoid too complex and irrelevant theorizing. Some of the scholars studied German sources, and for instance Claus

\footnotetext{
${ }^{4}$ Nils Jareborg, Handling och uppsåt. Norstedts 1969.
} 
Roxin and the doctrine of objective imputation received some attention, ${ }^{5}$ but still, in practice, such theorizing never really hit the everyday life of criminal law doctrine.

In the 1990's there was also a growing concern that the text-books were badly outdated. Then a few came out, and since then you may find somewhat different presentations of the concept of crime. Anyway, the differences between them are relevant rather pedagogically than theoretically or as regards the legal applications. None of those textbooks goes beyond a legal doctrinal level to any serious philosophical discussion.

In 1990 an international colloquium was organized in Helsinki to celebrate the first centenary of Finnish Penal Code. Tens of significant foreign scholars were invited to comment the first drafts for the revised general part of the Penal Code, namely the draft articles about elements of penal liability. The academic articles were published and they were taken into account in the preparatory work that followed. ${ }^{6}$ The revision was completed in 2004 when the new provisions entered into force. Even though some of the criticism was weighty, I would dare to say that already at this point the German scholarship had lost some of its authority. The Finnish law drafters were most likely also reluctant to adopt theories which were not very well known to them. We see here that the connection to the German legal culture had become thinner, and the law drafters were mostly concerned about the clarity of the rules to be proposed and that they would have a good grounding in the previous law and legal practice. It had also become clear that the Supreme Court was an important player. The Supreme Court had never been engaged in theoretical debates, at least openly, even though there were renowned criminal law scholars amongst the judges: Olavi Heinonen, a former associate professor of criminal law, later served as the president of the Court, to give an example.

Finnish criminal law scholarship was finally standing on its own feet as it was taking its first baby steps. And it had to learn to cope with a variety of new issues. There was not enough time engage with all possible theoretical and philosophical debates. A serious modernization of the

\footnotetext{
${ }^{5} \mathrm{Cf}$. the dissertation on criminal negligence: Ari-Matti Nuutila, Rikosoikeudellinen huolimattomuus, Lakimiesliiton kustannus 1996.

${ }^{6}$ Raimo Lahti - Kimmo Nuotio (Ed. by/Hrsg.), Criminal Law Theory in Transition. Strafrechtstheorie im Umbruch. Finnish Lawyers Publishing Company 1992.
} 
special part was underway and new issues were raised as a result. The so-called general doctrines was only one of such areas. There were other bigger issues. The system of punishment had to be reformed and the sentencing options broadened, membership in the Council of Europe and its ECHR triggered new issues as well as the fact that the European Union began to develop its approach to give framework rules on criminal law cooperation.

In the Finnish criminal law debate the relationship between criminal law and constitutional law became important, since also the constitutional law provisions had been revised in 1995, and the new doctrines on how fundamental rights may be limited were also applied in the criminal law area. This was not just plain theory since the Constitutional law committee of the Parliament started screening ex ante the compatibility of the proposed criminal legislation against the background of the fundamental rights as well and as the human rights standards. The Zeitgeist was not favorable to any philosophical critique of the valid law, but rather the question was how to adjust interpretations of different normative legal materials to each other. A pragmatist attitude prevailed. I will back to some of these issues later, towards the end of my presentation. We need to engage first with some discussions and debates that have been taking place rather on the level of legal theory.

\section{Criminal law as a science}

Empirical sciences would look at the practices of applying criminal law, but this is not typically what we do in law. If we accept that criminal law science can have norms as its objects, such a science will produce knowledge about criminal law norms.

These days the practical and the theoretical are intertwined. In contemporary societies we could not even think of a criminal law had we not been instructing the drafting and development of our laws with the help of legal research. Professional legal education means precisely this: knowing law is an academic enterprise, and the legal practice builds on theoretical knowledge. In the Nordic setting we could say that from 1960's onwards criminal law professors had to understand at least the basics of criminology and criminal policy and thus also, the phenomena of crime. There was no way back to a purely positivist legalistic approach. 
Sometimes a difference is being made between a legal order and a legal system to make precisely the point that legal science is able to present law differently, as an interpreted and systematic unity, which is more than just a set of norms. This may be an oversimplification, and certainly legal science can do more than that. In any case, the law itself and the legal science are today intertwined in a manner which makes it difficult to draw any clear distinction. Criminal law is the object of scholarly criminal science as a field of knowledge, but the science itself is also needed in order to construct criminal law (as part of the legal system, say, Finnish criminal law).

Criminal law scholarship or science is a practice, an activity which focuses on criminal law. It seeks to analyze, explain, present, construct, interpret, even criticize criminal law. Scholars use different methods in their scholarly work, and we have more than just one way of doing it. In sociological terms we might even define this scholarly activity as being what the criminal law scholars do. It is a joint enterprise of the scholarly community, and the community itself defines the necessary borderlines; it states what merits to be called legal science and what not. We do not even always have to be conscious of the limits of what counts as legal scholarship. Rather, we simply adopt views and definitions in our everyday practices, for instance, when assessing doctoral dissertations or when carrying out academic assessments in the context of professor recruitments. Certain types of studies count as merits as concerns recruitments, whereas some might not. I would claim that these days many more methods and approaches are being accepted in legal studies than the case was maybe a century ago. Research traditions such as law and society, law and literature etc may be marginal, but do exist.

In the field of criminal law also the link between research and teaching deserves mention: knowledge about criminal law is a requirement of a law degree. This, in turn, reflects the fact that lawyers may have to apply criminal law or serve clients that face criminal proceedings. We should avoid any too narrow definition of what counts as legal science. Criminal law scholars contribute to the knowledge of a system of criminal law, and therefore they should be aware of that impact and have a sense of responsibility. This expectation of a sense of responsibility is a plain fact which does not presuppose the ability to answer the deepest questions of ontological truths about criminal law normativity. Sending people to prison is a brute fact which shows that there is always a link to reality. 
In fact I would prefer speaking about criminal law scholarship rather than about criminal law science. This has to do with the fact that the methods used in criminal law research are not necessarily such that would satisfy strictest requirements of natural sciences. Law is not a thing you usually study in laboratories. You do not test hypotheses empirically. Legal scholarship may draw on knowledge from such kind of sciences, but most of what we do is something different.

Description of criminal law science as scholarly work tells to my mind better what this is all about. Scholarship aims at learned, informed, grounded views. Often we say that the aim of legal research is interpretation and systematization of law. Even though this does not tell much without further qualifications and explanations, there are at least some hints.

One important element there is that criminal law scholarship is meant to engage with legal practice, that is, the work of the legislatures and the work of courts when they deal with criminal law. Due to the fact that law itself can no longer hardly be understood without a legal education and the results of criminal law scholarship, we might even wish to include in legal practice legal scholars' work, at least in the broad sense, since the real life of law is always embedded in a scholarly setting. The law drafters, to give an example, need to understand the system of law; otherwise it would not make sense to adopt specific changes in that system.

Judges apply the law on the cases brought before them. Judges decide individual cases. The scholarly activities reflect on the legal issues on a higher level of abstraction. The judges are themselves engaged in a similar activity than what the scholars do, but they are more or less bound by the legal constraints of the case since the legal order itself imposes them restrictions as regards how law should be understood and applied. A judge is expected to follow some canons, conventions which are experienced as binding, concerning how legal sources should be organized, how conflicts of norms should be solved, and the like. Also certain conventions on style matter. We find in the world examples of very "scholarly" legal decisions with lots of references to sources, including legal literature, but in most cases the courts avoid such references and focus on reasoning directly serving the decision-making. 
The judge is however, without further qualifications, not a member of the academic scholarly community by the sole characteristic of sitting in court. When writing commentaries of law the judges jump into a new role; as scholars they have no privileged position to interpret the law.

Much of the canons on how to organize the legal sources and how to interpret the laws, and the rules and principles inscribed in them are in fact at least to some extent a product of legal scholarship. In order to perform his or her duties, a judge needs to know legal scholarship. Legal education is under the modern conditions the gate to legal professions.

Legal scholars working at the universities or research institutes in turn do not have the burden or privilege of having to decide cases. But, in order to produce knowledge that is relevant also for the legal profession, the legal scholar needs to share some of the core understandings of law the judge has. This is very central if the scholar wishes to contribute by his or her analyses to what the legal profession in more narrow sense are doing. This is a rather important feature concerning especially doctrinal work in the field of criminal law. It reaches out to the legal practice and it develops an understanding of it by building contexts in a way which a court could not do.

Of course criminal law scholarship may depart from this close link to the legal practice and choose to take other avenues. It can for instance reach out only to the community of scholars, or it might even mainly seek to address scholars of other disciplines. Most often, in any case, some link to the interpretation and systematization is being preserved. Comparative criminal law, for instance, looks at two or more systems of criminal law without giving a priority to any one of them. A work on restorative justice, to give an example, may present and discuss models of dealing with crime which are other than the ones we have now. Such knowledge may be important in reforming the procedural arrangements which we have.

The question of whether criminal law scholarship is or could be made a science most obviously leads to questions of how we understand law more generally. A Kelsenian theory would reduce the relevant questions to questions of validity of certain norms as part of a legal order. Questions of legitimacy or justice would not be permitted since a pure theory of law would not allow for 
that. A realistic theory of law would again seek to reduce law to facts as it would not allow for a normative perspective beyond that.

Courts are indeed interpreting law, but systematisation is something which falls mainly only the scholarly practice. This is due to the limitations that the courts face in carrying out their job. Systematisation could for instance be taken to mean all efforts aiming at maintaining the coherence of the legal system. The legal system is in constant change and there is always the risk of inner inconsistency. One of the traditional goals of legal science is to try to avoid inconsistency.

Why is it then in fact a problem? Why should we strive at consistency, and even coherence? The answer is simply that our normative commitments tell us so. We read our legal materials with the aim of being able to serve some core principles of justice. Equal treatment, legal certainty, principles of justice require that we should try to organize the legal materials accordingly. If two rules collide, one of them has to give way. Coherence of the legal system cannot of course always be granted, but it is a helpful ideal.

Coherence could be taken to mean coherence in terms of values and principles. If we regard criminal law materials in terms of weighing and balancing of legal principles, we see that interpretative activity almost by necessity has to strive to at least some sort of systematic coherence. These days criminal law has obvious links with constitutional law and the doctrines of fundamental rights, as well as the human rights law. The values and principles that criminal law is presupposed to cherish may have a backup in normative realms outside of criminal law in a narrow sense. Criminal law is part of larger normative settings.

In the scholarly activity of today we see rather much efforts in critical analysis. Criminal law is being criticized for being too formal. Women and their specific needs have been neglected. Rights of the animals play a limited role only. Criminal law promises too much and delivers too little. Criminal law is being used politically, as a means to an end, often excessively. ${ }^{7}$

\footnotetext{
${ }^{7}$ See, for example, the powerful discussion in Husak, Douglas, Overcriminalization. The Limits of The Criminal Law. OUP 2008.
} 
Criminological critique has stated that the state is stealing the conflict from the parties. What a strong metaphor! Criminal law is itself a crime!

Fragmentation of criminal law is one important topic. Do we any longer have a coherent legal order? Do the same general doctrines of penal liability apply across all the special part of criminal law (that is, the provisions on specific crimes)? I believe we are witnessing a certain fragmentation, and in fact the necessity to develop general doctrines that only apply for certain parts of criminal law tell precisely about this. International criminal law, to give an example, has developed new doctrines of its own, and as even domestic legal systems include provisions about these offences, it has been necessary to include provisions on specific doctrines of liability in the domestic legal orders.

We should now, after this brief setting of the scene, return to the question of the nature of legal science. First, to really be able to formulate requirements for the criminal law as a science, we would have to define what we mean by science. This is certainly not too simple, but if we would adopt a definition in line of scientific realism, we could say that science needs to tell about real world, and the claims of scientific knowledge would have to possess a truth value that can be tested.

As has been presented by Shin Matsuzawa elsewhere in this volume, Scandinavian realism á la Alf Ross could provide an example of theorizing which would satisfy rather high criteria of scientificity. This is indeed one option. We need to be mindful of the premises of the so-called Uppsala school and the Scandinavian realism that followed. It all started with the philosopher Axel Hägerström and his criticism of metaphysical thought. Hägerström criticized especially idealistic views about morals. For him, moral statements were only expressions of emotions. ${ }^{8}$

Vilhelm Lundstedt was the legal scholar who took the initiative to clean legal science from metaphysical thought. Lundstedt attacked the principle of guilt, for instance. Criminal law was seen in its social function only. For Lundstedt, the most important was to elaborate on the

\footnotetext{
${ }^{8}$ I have dealt with Alf Ross and Scandinavian Realism in my article Alf Ross som straffrättsfilosof. Nordisk Tidsskrift for Kriminalvidenskab 86 (3), 1999, p. 151-173.
} 
mechanism criminal law operates in the society. Even if the approach could be called social engineering, it was not a sociological approach. Criminal law played a role as it could be used to steer human behavior. It is crucial how this was thought to take place.

Whereas von Liszt and the sociological school had emphasized the special preventive function of criminal law, the Uppsala school and the Scandinavian realists emphasized the general prevention. The general prevention was, however, not understood as being based on the fear of punishment, as it had been presented by P.J.A. Feuerbach, for instance. Criminal law was understood to perform its function in that it was supporting and creating morals in the society.

How was it now possible to assign criminal law such a function, taking into consideration that talk about moral principles was non-sensical, only expression of emotions? For the Scandinavian realists the feelings and attitudes of the people were real, and these were now being used in steering people away from wrongful and harmful behavior. The function of criminal law was seen in the necessary moral education of the people. This, in turn, required that the emphasis should be given to the level of acts, not that of the actors. The level of action was seen as the mediating social level.

The idea of moral education as the aim of system of punishment was not a new one. It had been presented already by Ludwig von Bar in Germany and, as usual, most likely the traces could even be followed beyond that. ${ }^{10}$ As regards the Swedish scholars, Per-Olof Ekelöf was particularly interested in how criminal law performs its function in moral education.

In this sense, the Scandinavian realism was different from American realism. The former was critical and reductionist, but it did not change completely how law was being seen. One sign of this was that in the work of Alf Ross, doctrines of legal sources continued to play a role. The prediction theory was being applied, but it did not completely do away with legal reasoning.

\footnotetext{
${ }^{9}$ Lundstedt, Anders Vilhelm, Die Unwissenschaftlichkeit der Rechtswissenschaft. Zweiter Band. Erster Teil. Berlin 1936, p. 25 pp.

10 Von Bar, Ludwig, A History of Continental Criminal Law. Little etc, Boston 1916, pp. 497-547.

${ }^{11}$ Ekelöf, Per Olof, Straffet, skadeståndet och vitet. En studie över de rättsliga sanktionernas verkningssätt. Uppsala 1942, pp. 12-74.
} 
For Ross, law operates through the mind of the judge. The judge feels being socially bound to law and thus attaches it a normative meaning. A purely behaviorist analysis could never reach this mental link which accounts of the validity of legal norms.

A prediction theory (or: a prognosis theory) leads to problems if the validity of law is being denied completely. The most obvious problem is that if we adopt the position of a judge who is sitting a difficult case and faces a problem concerning how to interpret the law, it does not help the judge further to ask the question about his own future behavior. He (or she, for that matter) is not in need of a prediction of his own future actions, but instead he needs help in reasoning for a good judgment. ${ }^{13}$ So we fall back on the issue of normative reasoning. In easy questions it may indeed be possible to do this transforming operation, but dealing with easy cases is not the core function of what the courts do. And routine cases are not too interesting from the point of legal scholarship either. Easy cases are easy precisely because we know how they should be solved. It is not a surprise that much of the legal thought focuses on reasoning in so-called hard cases. The work of Ronald Dworkin provides the well-known example. For him legal reasoning is an effort in constructive interpretation.

Kaarlo Tuori has pointed out that Hart's critique of Scandinavian legal realism misses the point. The aim of the realists was to reformulate the basic legal concepts so that legal dogmatics could pass the test of scientificity rather than to change the character of all legal research. One obvious merit of the work of Ross, for instance, was to elaborate a more fine-grained conceptual framework of the concept of property; one which contained a set of relationships and one which made it possible to see that various rights could the transferred at different times during a process of change of ownership. The realist redefinition was thus in fact better equipped to matching with the needs of a dynamic market economy than a classical concept formation á la Begriffsjurisprudenz. ${ }^{15}$

\footnotetext{
${ }^{12}$ Cf. Alf Ross, On Law and Justice, University of California Press, 1959, Ch. 2.

${ }^{13}$ This critique was presented by H.L.A. Hart when he wrote the review of the book by Alf Ross. H.L.A.Hart, Scandinavian realism. Cambridge Law Journal, 17(2), pp. 233-240, at p. 237.

${ }^{14}$ Cf. Ronald Dworkin, Law's Empire, 1986.

15 Tuori, Kaarlo, Ratio and Voluntas. The Tension Between Reason and Will in Law. Ashgate, 2011, pp. 124-129.
} 
Ross was famous for his criticism of use of concepts that do not have a reference in reality. He used the word ' $T \hat{u}-T \hat{u}$ ' to describe such concepts. For him, 'guilt' was one of such metaphysical concepts. When Ross wrote about criminal law, he had already moved more towards analytical philosophy. He reinterpreted the principle of guilt in terms of the opportunity to act otherwise. This has been called the principle of conformity. Together with this move, the significance of language and linguistic analyses grew. It was no longer that important to follow the program of Scandinavian Realism and accordingly, even moral and legal expressions could be studied by using the tools of language. ${ }^{16}$

It is rather interesting that even though the Scandinavian Realism faded away, some of its core views have continued living. The idea that criminal law serves the interest of moral education entails a rather different look at how prevention works compared to hard general deterrence. This so-called positive general prevention sees the people as basically lawabiding, and the point of criminal law is to strengthen this attitude. In terms of criminal policy, this approach avoids the risks that failed prevention always motivates harsher criminal punishments. It is no wonder that in the Nordic countries as well as in Germany, for instance, the crime policies have been more moderate than U.K. or U.S. which have witnessed the punitive turn. Even the crime policy approach of the European Union seems to have adopted a somewhat harsher deterrence view than the one based on positive general prevention. ${ }^{17}$

This brings us to the other obvious option for a realist and scientific legal thought, namely, law and economics. In fact most of law and economics studies should rather be placed on the level of legislature than on the level of adjudication. Law and economics scholarships is based on a utilitarian theory that legal rules should contribute to the good of the society. Law and economics also includes some presuppositions concerning how people choose and behave. Individuals are seen as maximizers of their interests, especially economical interests. Behavior of such individuals can again be steered by adding the cost of harmful behavior in order to steer the behavior of individuals towards acting within the limits of what is lawful.

\footnotetext{
${ }^{16}$ Ross, Alf, On Guilt, Responsibility and Punishment. Berkeley and Los Angeles 1975.

${ }^{17}$ Cf. Nuotio, Kimmo, A Legitimacy-based Approach to EU Criminal Law: Maybe We Are Getting There, After All. New Journal of European Criminal Law, 2020, 11(1), 20-39. https://doi.org/10.1177/2032284420903386
} 
Even this conceptual framework is rather reductionist since it grasps human action only from the point of view of economic interest, and it also presupposes a certain model of rational action which the individuals are suggested to be following in their decision-making. Richard Posner has observed that if only Jeremy Bentham's 'pain and pleasure' -principle be interpreted to mean cost and benefit, Bentham could be seen as having introduced an economical analysis of non-market behavior. This made law and economics possible. ${ }^{18}$

Reductionist approaches seem to lead to over-simplified models of human action. From the point of view of reductionist theories it may not be helpful to try to formulate subtle and finegrained theories of culpability, for instance, since why would this be needed, if such normative principles do not have any real standing of their own? The entire legal doctrinal work of scholars seems rather redundant and unnecessary, if the law is being regarded in its regulatory function only.

During the last years, interestingly, law and economics has been challenged from the inside. The behavioural sciences have progressed which has led to an important critique of the rational action model which is so central for law and economics. Namely, empirical research has shown that human beings reason very differently from what has been suggested. Human mind reasons mostly rather intuitively and it tends to make systematic errors in exercising its capacities in the actual world. This has led to efforts to rescue the law and economics by adding new insights to it, which merits the name behavioral law and economics. ${ }^{19}$ Such corrections may be necessary from a theory-internal point of view, but still, as concerns a full theory of criminal law as we know it, the problem of being far too reductionist stays. Behavioral sciences could and should feed into the legal realism as well since maybe what the courts do is not so rational after all. The various biases that the behavioral sciences have found in human decision-making may be present in the actions of the courts as well. Anyway, this is of course precisely what the

\footnotetext{
${ }^{18}$ Richard A. Posner, Frontiers of Legal Theory. Harvard University Press, Cambridge 2001, p. 54-55.

${ }^{19}$ See, e.g., Russell B. Korobkin, Thomas S. Ulen, Law and Behavioral Science: Removing the Rationality Assumption from Law and Economics, 88 Clif. L. Rev., s. 1051-1144 (2000); Richard H. McAdams, Thomas S. Ulen, Behavioral Criminal Law and Economics, (John M. Olin Program in Law and Economics Working Paper No. 440, 2008).
} 
argumentation theory seeks to counteract in making sure that the reasoning of the courts would pass a test of intersubjectivity.

This is all the more important if we take into account the so-called linguistic turn. The point is that there is actually no direct entry to the world as facts without involving the means of language. And the way language relates to world as an external point of reference cannot be grasped as if we would produce in the language a model of the real world, a kind of a picture of this real world. There is no way we could check that we have the things right. Therefore a correspondence theory of truth cannot give us definite answers; there is no way we could reach beyond language.

We could also add here a brief note regarding the use of artificial intelligence in (criminal) law. If we look at recent trends in applying artificial intelligence and similar technological tools in reasoning, we face a problem. It might indeed be possible, at least in theory, to replace the courts by machines which could deliver the same quality of end products. But that would presuppose that we were able to formalize all necessary legal reasoning in the form of algorithms. There is a long way to go before we could trust such predictions. It is precisely the quality of legal reasoning which creates trust and accounts for the legitimacy of the entire legal system. The principles of justice themselves need to be articulated.

The legal system is a product of two levels of legal reasoning; we have the levels of law-making and legal adjudication, and we have the level of legal scholarship. Legal scholarship aims at presenting the legal materials in a coherent manner, also explicating the inherent values and principles. This holistic feature renders formalization of what courts do extremely difficult. The task is actually very difficult even for human beings, and that is part of the attraction. The courts need to work to achieve high quality, even if there cannot be any final guarantee that a court ever could reach the best possible solution. The more we understand that the legal system is a construct and that by changing some of the presuppositions within this construction the entire game may change, the more we appreciate legal reasoning. And legal reasoning is also the 
stepping stone for a critical analysis of law. A critical analysis aims at challenging, either in a particular context, or even more generally, the objectivity of legal knowledge. ${ }^{2}$

Theories of law which would satisfy the requirements of scientific realism would in fact have to be of reductionist nature. As regards criminal law, such an effort seems to risk losing much of the achievements that the elaboration of concepts and principles of penal liability has delivered in terms of coherence and also in terms of a justice perspective. Are we really willing to sacrifice all this just for the sake of meeting criteria set by such sciences which emphasize controllability and empirical nature of legal knowledge? We also need to ask why an empirical approach would be needed. It is only for scientific reasons? We should, namely, be aware of that the Scandinavian Realism was also connected to a social engineering perspective. Knowlegde about practices of law was instrumental - in the true sense oft he word - in running the society. If we believe that criminal law should rather concern something else, if we take it to be a way of organising freedoms in a society and not only suppressing harmful behavior, I believe that we will have to avoid purely instrumental theorising of law and social life.

If we can say that the reductionist theories of law cannot handle criminal law in a way which would account for its inherent values and principles, we need to be searching for other avenues. Could we justify criminal law and criminal law scholarship any other way, as some kind of reconstructed normativity?

This is maybe as good as it gets. Reducing criminal law contents to meet the standards of empirical sciences seems not to work. But maybe we could look at the legal doctrinal work as a practice of explaining and justifying the contents of law in the normative realm? It seems to me that such an effort would not be waste of time since it may be that what we really expect criminal law theorizing to provide is an account of the central principles that stand for its coherence and fairness. If we wish to say, for instance, that the principle of guilt excludes introducing of strict liability as a form of liability in criminal law (according to the criminal law of England and Wales, in fact strict liability applies for so-called regulatory offences), this is a matter of principle. We may wish to discuss and debate what we mean by guilt and culpability

\footnotetext{
${ }^{20} \mathrm{Cf}$., for instance, the famous work of Martti Koskenniemi, From Apology to Utopia. The Structure of International Legal Argument. Cambridge University Press, Cambridge 2005.
} 
in criminal law and what consequences the various concepts and understandings may have, but nevertheless there is no external final point of reference we can point at. All this is a matter of normative reconstruction. Many discussions today are difficult and we just have to work out best possible solutions. In Finland there is some law-drafting underway to scrutiny whether a process for medically assisted suicide should be introduced by issuing new legislation. Not having a regulated procedure causes not only the risk that some people have to suffer more than necessary, and also a possible contributor may face harsh punishment. But again, having a procedure would risk overuse and would bring matters of life and death on the table of human decision-making.

One of the characteristics of science is that it is able to establish at least some sort of controllability of its results. A normative reconstruction of the contents of law is a paradigm which fulfils at least some of such conditions. Accordingly, it will be possible to organize the body of knowledge and present it in a systematic fashion. There will be a point of view of critical assessment and critical insights. In social sciences and humanities much of scholarly activity deals with conceptualizing phenomena. This is what we do. Our conceptual tools and our work with principles enables us to search justice by way of pointing out deficiencies and injustices.

Criminal law scholarship according to continental or Nordic understandings is rather obviously characterized by this systematic nature of the enterprise. One of such features is the aim to present the concept of a crime as an umbrella concept. Accordingly, all general prerequisites of criminal liability could be presented as occupying a place in the structure of crime understood in this meaning of a systematic and coherent totality.

\section{One step back towards a normative understanding of criminal law}

If we take a look at the case of Finnish criminal law and the scholarly activities in that field, we could see a certain return of the normative approaches. As we mentioned above, 1970's was a time of starting the comprehensive reform of the Penal Code, an effort which was a product of an in-depth critique of the then prevailing views and of the outdated legislation. The ideological premises which the law had been built upon simple had lost much of their credibility. Belief in 
punishment as treatment had proved illusionary. The new way of thinking about criminal justice built on much more cautious presumptions concerning what criminal law can deliver. The entire area of criminal law had to be reassessed.

The point was, in fact, not so much to criticize criminal law on the basis of the lack of a scientific basis. It was much more the case that the values informing the legislation were outdated. The special part did not represent a modern view of what role criminal law should be given in various fields of life. The views concerning the purposes of punishment were outdated, and the penal sanctions were being used way too easily, without a real consideration of the costs and consequences of running such a system.

1970's saw interesting new phenomena, such as the rise of Marxist critique of criminal justice. That was, in any case, in Finland a rather marginal phenomenon. The legal reforms were in fact supported broadly by the academic community. For the first time not only lawyers but also experts in sociology and legal policy participated in drafting the principles that should guide the work towards the reformed Penal Code.

The reform meant that criminal law was being looked at from new perspectives, especially that of criminal policy. An overall theory of the legitimate aims of criminal policy was created. The biggest difference vis-á-vis the previous thinking was that crime should not be combatted at any cost, but rather criminal policy should be based on realistic expectations. Crime cannot be made disappear. The policy of reacting to criminality needed to be based on sound values and rational principles. We could say that elaboration of such principles was also a scientific effort. Not only was this part of general policy making affecting and informing legal studies, but it could draw on also empirical knowledge from other fields, mainly criminological studies.

If we look at this new contextualization of criminal law scholarship, it certainly changed the landscape. The situation is maybe not all that different than was the case of (West-)Germany, when the local criminal law reform started and the Alternativentwurf drafted by the leading professors was presented. For Finland the broader context of criminal policy was even more significant. We should, however, note that for instance in the work of Claus Roxin the role of 
criminal policy was very significant since he tried to build his doctrinal views on penal liability on the broader criminal policy goals. ${ }^{21}$

If we think about the impact of the big reforms on the so-called general part of the criminal law, and especially on the doctrines of penal liability, the new insights did not change the landscape completely. It seems that even tradition plays a role. These are doctrines that have developed over the years, and there is a constant interplay between the scholarly interpretations and the application in practice. During the 1970's, when the legal policy approach grew important, in Finnish criminal law scholarship rather little interest was addressed to the details of the general doctrines. One could say that the general doctrines remained traditional longer than some other parts of criminal law.

As regards the case of Finnish criminal law scholarship, the textbooks by Brynolf Honkasalo need to be mentioned. He was a scholar who knew very well the German scholarship of the 1920's, and he produced a set of textbooks and commentaries, which remained significant up until 1990's, when new textbooks started to be published. The doctrines presented by Honkasalo continued playing a role since every educated lawyer knew that body of work which therefore influenced heavily the scholarly thinking of all relevant actors in the field. Honkasalo could be characterized as a professor who defended legalistic values during a time when also less legalistic views were present - to put it mildly. Honkasalo was a classical legal scholar who was not much worried about whether what he was presenting was scientific or not. The level of reflection did not reach that deep.

A legal tradition has a strange feature that it may grow deeper. As concerns Honkasalo's views, his way of thinking filled in many of the gaps that the legal provisions did not have answers to. The Penal Code of 1889/1894 was rather scarce on rules regarding the general part. Kaarlo Tuori has in his theory of critical legal positivism maintained that the legal phenomena can be looked at on three different levels of law. ${ }^{22}$ On the surface level we have the turbulent flow of cases and individual legal decisions as well as the fragments of legal norms. Underneath this

\footnotetext{
${ }^{21}$ Roxin, Claus, Kriminalpolitik und Strafrechtssystem. 2. Auflage. Berlin, New York 1973.

22 Tuori, Kaarlo, Critical Legal Positivism. Ashgate, Aldershot 2002.
} 
level, in turn, we see law as a legal culture, law in the light of legal concepts and general doctrines of law. On the deepest level of law we have the most fundamental constituents of our legal thinking, that is concepts such as legal subjectivity. They are presuppositions of legal thinking and they characterize a certain legal form. Changes on this level are rare, since such shifts might lead us to a completely new epoque.

Tuori's theory of the symbolical-normative levels of law helps us see how tradition works in defining the legal culture. Honkasalo's views were important in the development of this particular aspect of legal culture simple because they represented the dominant way of thinking and theorizing, and in this way, over the years, they grew in importance.

The general part of Finnish Penal Code was reformed in 2004. On that occasion, however, it was not just about codifying existing practice but on some points Honkasalo's views had already lost dominance. We could take the definition of criminal intent as an example. Honkasalo was a proponent of so-called will-theories. The direction of the will of the perpetrator was decisive as far as the intent was concerned. During the 1970's a concurrent model which was called the probability model of intent gained a foothold. Such doctrines were known in other Nordic countries, especially in Denmark and Norway. Since the doctrine of intent is so central when determining penal liability, it was regarded important for reasons of legality principle to formulate the doctrine in written text of law, even though it was known that in most penal codes oft he world one would not have a provision on that.

The new model had been identified by the law reformers, and it had also already some influence on the case law of the Supreme Court of Finland especially in cases in which a drunken person had killed another by stabbing with a knife. Often the perpetrator could not give clear reasons why he had stabbed since maybe the entire group of persons involved had been drinking heavily. From the point of view of bringing evidence on the circumstances it was easier to prove that the perpetrator had regarded the deadly outcome as probable compared to defining the precise direction of the will. In the law reform, a probability concept of intent was finally codified. It only applies, however, with regards intent vis-á-vis the consequences of the action. 
Later the Supreme Court of Finland has broadened the probability concept to be applied also for intent which refers to a circumstance at hands during the committing of the action.

The legislature was in a way a bit unsure how to handle the situation since it was understood that defining legally the doctrine of intent without a will element might produce strange consequences in some areas other than drunk killings. But the legislature trusted that the Supreme Court will find ways solve the necessary problems. It has been working on these issues quite a lot during the recent years, testing the doctrine and fixing some slight modifications to it. It seems that ultimately the choice of doctrinal lead concepts and principles have to be based on justice considerations, even though other considerations may be relevant as well. As regards criminal intent, even the psychological contents need to be credible.

Thus it seems clear that albeit the forces of tradition play a role, even on the level of legal culture changes may occur and, as in this case, be purposefully introduced. It is no wonder that some of the views held by Honkasalo had to be abandoned since they had been created for a completely different situation. The will-based construction was being regarded too broad in terms of criminal policy reasoning whereas the probability model of intent was better adjusted to the criminal policy reasoning. Anyway, there are some slight indications that even the new model might be need another look.

The Supreme Court dealt with one case in which the accused had twice pulled the trigger of a roller revolver that he had pointed from close distance to the face of another person. ${ }^{24}$ There was one bullet in the roller, and the roller had been rolled in between the two events. It was all random so that the gunman did not know whether pulling the trigger would result in a shooting or not. Luckily nothing happened. The Supreme Court dropped the charges concerning an attempted killing since it had been, from the point of view of the gunman, more likely that the shooting would not take place than that it would.

\footnotetext{
${ }^{23}$ Kimmo Nuotio, Todennäköisyystahallisuuden tilasta ja tarinasta, Lakimies 7-8/2017, 970.

${ }^{24}$ Supreme Court of Finland, Judgement 2013: 82.
} 
In fact, the probability of a deadly outcome would after two random trials would be roughly $30,6 \%$; after three random trials $42,1 \%$, and first after four trials would we cross the line of $50 \%$, namely it would now be $51,8 \%$. The probability of a single event is $1: 6$, and the events are not related. Most likely the judgment of the Supreme Court went almost without a notice, since it was a logical application of a settled doctrine. But, we should ask, would the Supreme Court have followed the same line of thought even if the victim had been less lucky and if he or she had been killed in this strange game. This was the question that I raised in the article referred to above. Our intuition becomes much more unsure. Modern psychology even teaches that human minds are not very accurate in assessing probabities. The law-drafters in a way anticipated this when stating that crucial should be an everyday view on probability instead of a mathematical or statistical calculation. This is clearly a wise note, but then we could add another one: do we know then how to apply that probability intent principle? How much progress have we made by adopting the new theory?

In the 1970's the neo-classical school of thought, if we wish to use this name which is only partially fitting, formulated the lead values of criminal justice system very differently from its predecessors. Individual prevention as well as blind retribution or hard general deterrence were abandoned, and a more modest view of what criminal law can deliver was adopted: criminal law should be about communicating blame and blameworthiness. This communication should be understood rather as a symbolical enterprise than a strict way of enforcing these values in a society. Rule of law should prevail, which meant that values of act-proportionality as well as the principles of legality and guilt should be recognized as lead stars.

As for Finland, something very interesting has followed. The constitutional law framework has grown in significance with relation to criminal law. In the 1980's the principle of legality with its four sub-rules or sub-principles mainly only existed as a construction of criminal scholars, a decade later it had the support also on the level of human rights law as well as constitutional law. In 1995, the new bill of rights of the Finnish Constitution entailed a provision on this matter. The wording of it was, as can be expected, rather close to what the European Convention of Human Rights equally provided.

In terms of Tuori's critical legal positivism we should state that the principle of legality gained increasingly institutional support from norms of a constitutional nature, which of course 
strengthened this principle strongly. From now on the legal doctrinal work had a new task: to explain how the various provisions about the principle of legality in criminal law should be interpreted when applying domestic law in individual cases. Criminal law and constitutional law became closer to another. A normativist reading of these legal materials was needed as the doctrines of legal sources had to be enriched. It would have been a very difficult effort to try to reduce all the relevant normative materials to some predictions á la Scandinavian realism. The heyday of Scandinavian realism had already passed. The weak ambitions of neo-classical ideals became stronger as the novel principles now could be embedded in a constitutional framework.

It may deserve a mention, however, that the same period of time not only meant a sedimentation and victory of neo-classical values, but there were also signs of disruption. Neo-classical thinking had proclaimed a simple system of criminal sanctions which would increase the legal certainty and make the system more transparent. The search for alternatives to punishment together with new models that had been tested in other Nordic countries, the system of punishment was enriched by elements unforeseen in the 1970's. Community service, for instance, was introduced in order to promote the reintegration of the society of the convicted. Anyway, it was not quite simple to find the right place for it in the existing system of punishments. It obviously was a sanction which only could be applied in case where there was a good chance that the convict would be able to serve the sentence in this form. Victim-offender mediation was also a novelty which originally was meant to take place completely in the shadows of law. Later, it was being formalized, however. Victim-offender mediation was a new out-of-court practice which grew out of insights drawing on critical criminology. The system of punishments grew more complex, but this could be regarded as a positive development since it allowed for a more reasonable choice of punishment and determining of the criminal sentence, albeit to some extent at the cost of the values of simplicity and legal certainty.

Constitutionalisation of criminal law is a feature which certainly changes the normative framework somewhat. Norms other than criminal law have to be taken into account. In fact the constitutional provisions usually do not control legal adjudication by giving strict rules, but it is rather a matter of giving normative guidelines. Another even more important feature is that the constitutionalisation of criminal law not only brings constitutional law to the criminal law field, but it also creates a common ground for criminal law scholars and constitutional law scholars. Scholars need to start getting interested in each other's fields, since neither of them 
can restrict themselves to the relevant provisions only; instead, it is a matter of interpreted provisions, and partly the interpretation is again a product of scholarly work.

Is there any sign here that the science of legal scholarship has progressed? Is the new model of criminal intent scientifically more sound than the old one?

It is not that easy to answer such questions. In some sense the probability model is more realistic than ist predecessor since certainly theorizing about the direction of the will was more strongly founded on metaphysics. One of the targets of the Scandinavian realists was precisely the metaphysical concept building which had a long time been an important part in the German criminal law theorizing. ${ }^{25}$ This, of course, is no wonder, since during the $19^{\text {th }}$ century Hegelian thinking was, to give an example, strongly present. There may have been an effort to avoid unnecessary use of metaphysical concepts. Talk about probability could also be more easily be linked with criminal procedure and especially the ways intent could be proven in a concrete case. You might thus interpret this as a step towards more enlightened and scientifically minded theorizing. But, one could almost quite as well just name it an example of a general Nordic pragmatism. The thinkers and actors who were engaged with this issue maybe simply were interested in developing a formula which would be good enough to serve in the daily life of courts and legal practitioners. The concept-formation was being looked at from the point of view of rationality in terms of criminal policy.

If we look at the big picture of the development of Finnish criminal law, we might really see some rather punctual points in which the scientific progress or scientific knowledge have had an influence. But in fact no ground-braking revolutionary reform of the entire body of criminal law knowledge at the same time. Scandinavian realism never really hit the market in Finnish criminal law. This may have been a matter of timing. The Finnish law reforms started far too late. Certainly, Scandinavian legal realism may have inspired some criminal law scholars especially in the 1970's or before that, and maybe this was one of the reasons they were so willing engage with new ideas. But we should not say that what they did was just an application of Scandinavian legal realism. This would be a clear exaggeration.

\footnotetext{
${ }^{25}$ See, e.g., Kaarlo Tuori, Ratio and Voluntas. The Tension between Reason and Will in Law. Ashgate, Farnham 2011, p. 124-129.
} 
The question about scientific ideals and how they have been received among circles of criminal law scholars is, however, an interesting point of even more generally. We might think of phenomena such as an almost Darwinist emphasis on biological roots of criminality in the beginning of $20^{\text {th }}$ century. The sociological school headed by Franz von Liszt gained the support of biologically informed scholars. Von Liszt and Karl Binding were the leading proponents in the Schulenstreit, in which von Liszt was arguing for a positivist and utilitarian model of criminal sciences. It looked progressive to seek to protect the society against the threat posed by dangerous criminals, especially the habitual criminals. Special treatment of dangerous recidivists was introduced in Nordic countries; in Finland the legislation entered into force in 1932. Such features which at their own time seemed rational and which in fact really also were based on science of the time, would later look like outdated and in many ways inefficient and harmful ways to react socially on crime. The new social policy -based approach in the 1970's aimed especially at replacing the remains of such old doctrines.

Thus, we should maybe not even seek to purify all criminal law scholarship from materials which cannot be based on science. Instead, we could say that criminal law scholarship has often at least in some ways reflected the general trends of scientific thinking, especially when thinking about the models and ideals adopted.

Finnish criminal law scholarship has maybe not been very strong in reflecting on its own development. Only few sources could be cited which aim at presenting the traditions and storylines of Finnish criminal law scholarship. The criminal law professors have been too busy in doing their daily job.

We could finish by commenting with few words the German criminal law scholarship. German scholarship was especially in the late $19^{\text {th }}$ century an important source for Scandinavian and Finnish criminal law knowledge. The significance of it in fact grew weaker mainly after the world war II, when the anglo-american influence became visible together also with the rise of the social sciences including criminology. 
The German criminal law scholarship has, however, continued its work domestically. In the globalized world of today, German criminal law scholarship has found new niches of influence and export. Especially Latin America and Asia have been important regions of academic influence. It has been interesting to note that for instance Japanese scholars often have been trained in German criminal law scholarship so well that they can reproduce even the finest doctrinal achievements of the German elite scholars. Markus Dirk Dubber has claimed that this is a result of longterm conscious effort to export German criminal law thinking by inviting foreign scholars to Germany, to provide language education of them and to support their work to carry the torch further. Textbooks, such as the one by Claus Roxin, have been translated to foreign languages and are being used in teaching lawyers locally.

This phenomenon is interesting in itself since it tells about the power of developed criminal law theorizing. Importing or exporting criminal law doctrine is, however, not quite unproblematic. We might read this as a way of colonizing academic communities by bringing in completely new doctrines, maybe as adjusted to fit the local needs. This is what scholars have always been good at. But what is special about this movement is the sheer volume of the German scholarship. Hundreds of professors have for two hundred years researched criminal law and have over the years worked out a certain conceptual system, the main contours of which they are able to share. This has made it possible to create the "general doctrines" of penal liability.

There is nothing wrong with such an effort. I would, anyway, make an observation concerning the situation now, compared with the one which existed in the $19^{\text {th }}$ century. In the Nordic countries quite clearly very few scholars would any longer recognize this sort of superiority of German legal scholarly work. This results from the fact that the Nordic legal orders have created their own traditions. They have continued discussing some of the findings of German criminal law scholarship, but German scholarship operates rather as a point of reference than as a source to be copied and introduced. This fact that a legal culture develops on its own right, on its own terms, could be seen as a sign of maturity. The Nordic criminal law and the Nordic criminal law scholarship are standing on their own feet, finally.

If you wish as a scholar to develop your own doctrinal system of criminal law, how should this happen? Is it best to borrow from more developed legal cultures, or should you work rather towards building something own? This is a very central question. Maybe we should start by 
stating that borrowing might be a good solution if you can trust that either the doctrinal solutions are universally valid or that they are expressing values and principles which can be shared in both societies. Probably a modern (or post-modern) understanding rather sees doctrinal efforts as not universal, but precisely work in progress.

If we see doctrinal work as work in progress, then we should ask about the drivers of that progress. If I'm right, critique of a doctrine always or almost always in some sense presents itself in terms of academic validity and credibility. Justice problems have always been the drivers when former doctrines have been attacked and new doctrines proposed. I would claim that probably this link to justice considerations is what ties doctrines to the own society and to the perceptions of justice involved. For that reason a mixture of borrowing and developing the own, internalizing the results, may be a way forward. In some articles included in this volume we find interesting remarks concerning how to handle the dilemma.

Accordingly, we could say that the criminal law scholarship seems to be able to contribute to the development of a legal culture which may be national or regional, but most obviously we are not witnessing any strong movement towards a unitary world criminal law doctrine and scholarship. Too many forces are pointing to the other direction. The power of the quality of dogmatic work is not enough in order to lower the borderlines between various legal orders. Criminal law scholarship continues thus to be somehow relativist: it is relative to the needs and challenges of the particular legal and political communities in which the law lives. Harari has written in his Homo Sapies about the trend towards unified thought models in the modern societies. Criminal law seems to be one of the areas where we could see increased communication in the scholarly world. It would, however, be premature, to take this to mean that we are moving towards a more universal and unified criminal law doctrine.

\section{Where to go next?}

In his book on "The Dual Penal State" (2018) Markus Dubber has suggested that we could analyse the criminal law from the point of view of two different modes of government; law and police. The first one takes the liberal legal-political project into account and could be called citizens' criminal law whereas the police mode of governance locates the issues to be dealt with 
by a prerogative state, as managing objects rather than persons. This second mode comes close to the enemy criminal law, a term coined by Günther Jakobs in Germany.

Dubber's proposal for criminal science is to start with a critical comparative-historical analysis in other to win insights of what the liberal legal-political project has achieved, and even more so, of its failures. What is important in the suggested task for legal science is to dig deeper than just interpretation and systematization; instead, we should reach the level of mode of governance. The idea of using such a critical analyse hangs together with the second part: that we should work towards solving - if possible - this fundamental penal paradox by bringing in the normative expectations created by the liberal legal-political project. This project was started by the Enlightenment and it still is a unifying factor in Western societies. Our problem is, however, that we have never really lived according to the expectations. The point is that we would need a new type of dialogical, transnational science of criminal law, which would focus on these premises and conditions which stands for the legitimacy of state penal police qua law, as law. ${ }^{2}$

Dubber's work is an anti-thesis of a thesis which would seek to reduce criminal law and the scholarship around it to any science in the strict sense. According to his analysis the involvement of a scientific approach has rather often derailed the project of criminal law from its liberal legal-political premises. The fundamental questions concerning the legitimacy of law, and in fact, use of penal power, cannot be easily met by strictly scientific tools. Not even the criminal law doctrines would always be enough to grant this legitimacy to the use of penal power, since even scholars have contributed to the emergence of enemy criminal law by proposing norms and systematizing them.

The question of what really counts as science is thus worth asking. Maybe we should not be too strict in limiting ourselves since otherwise the obvious risk is that we lose something important, or even the most important content. The choice of methods also depends rather obviously on

\footnotetext{
${ }^{26}$ Dubber, Markus Dirk, The Dual Penal State. The Crisis of Criminal Law in Comparative-Historical Perspective. Oxford University Press, Oxford 2018. Cf. Nuotio, Kimmo, The Dual Penal State á la Markus Dirk Dubber. Bergen Journal of Criminal Law and Criminal Justice, vol. 6, no. 2 (2018), pp. 178-187. https://doi.org/10.15845/bjclcj.v6i2.2723.
} 
what we are aiming at doing. Are we the critics, and with reconstructing, what do we do, actually? I would be especially cautious in adopting reductionist methodologies which measure the law from the point of view of another rationality. It seems that certain questions are especially inviting new scientific approaches, namely questions for which you do not have answers in law. Think about the release on parole from a life sentence. Or other similar instances in which the legal rules require assessment of risk of reoffending. How can we tell that?

We can use medical understandings, or we could play with statistical data, we can fill in the gap with any relevant knowledge. But predicting human behavior is a very different task than judging acts already committed. A citizen's criminal law seeks to reduce precisely those points in which the law has very little to say and human action is being regarded from another angle, that of taking the person as an object, as a risk factor, and not as a citizen, a person with a capability to commit to law, should he or she so wish. Sometimes the shift of perspective is only a small one. But this shift means a lot in terms of what kind of law we are talking about.

Thus, the way we define the limits of science in criminal law scholarship has an impact on what we are studying, in fact. And even more: we may mean different matters with criminal law. I believe we should try to be clear about what we believe we should be doing when engaging in criminal law scholarship or criminal law science. There may be situations in which a more critical approach is being called for, and situations and times where and when more reconstruction is needed. Criminal law scholars have the advantage that they can make use of all the various methods and approaches that are generally available in legal studies. Criminal law is also the field where there is a long tradition of interdisciplinary and multidisciplinary approaches. Thinking in alternatives and learning from others always remains an option. 